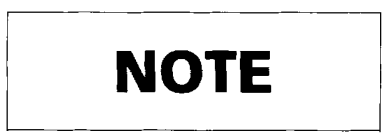

1 Department of Food Science and Technology, University of Reading, Reading RG6 6AP, UK

2 Culture Collection, Department of Clinical Bacteriology, University of Göteborg, Sweden

3 SAC Veterinary Services, Inverness, UK

\section{Characterization of a novel Gram-positive, catalase-negative coccus from horses: description of Eremococcus coleocola gen. nov., sp. nov.}

\author{
Matthew D. Collins, ${ }^{1}$ Mar Rodriguez Jovita, ${ }^{1}$ Paul A. Lawson, ${ }^{1}$ \\ Enevold Falsen ${ }^{2}$ and Geoffrey Foster ${ }^{3}$
}

Author for correspondence: Matthew D. Collins. Tel: +441189357226. Fax : +44 1189357222.
e-mail: David.Collins $a$ bbsrc.ac.uk

Two strains of an unknown Gram-positive, catalase-negative, facultatively anaerobic coccus originating from the reproductive tract of horses were characterized by phenotypic and molecular taxonomic methods. Comparative 165 rRNA gene sequencing studies demonstrated that the two strains constitute a new subline within the lactic-acid group of bacteria, close to, but distinct from, Abiotrophia defectiva, Globicatella sanguinis and close relatives. The unknown bacterium was readily distinguished from other described Grampositive, catalase-negative cocci by biochemical tests and electrophoretic analysis of whole-cell proteins. On the basis of phylogenetic and phenotypic evidence, it is proposed that the unknown bacterium be classified as Eremococcus coleocola gen. nov., sp. nov. The type strain of Eremococcus coleocola is CCUG $38207^{\top}$.

Keywords: Eremococcus coleocola gen. nov., sp. nov., taxonomy, phylogeny, 16S rRNA, horse
The Gram-positive, catalase-negative cocci constitute a phenotypically heterogeneous group of organisms within the Clostridium subphylum of the Grampositive bacteria. In the 1986 edition of Bergey's Manual of Systematic Bacteriology, only six genera of Gram-positive, catalase-negative cocci were listed (Sneath et al., 1986). During the past decade, the number of described genera and species of Grampositive, catalase-negative cocci has increased considerably. Some of these new taxa have resulted from the taxonomic reorganization of existing genera, such as Enterococcus and Lactococcus from the genus Streptococcus; Oenococcus and Weissella from the genus Leuconostoc; and Tetragenococcus from the genus Pediococcus (Collins et al., 1990, 1993b; Dicks et al., 1995; Schleifer \& Kilpper-Bälz, 1984; Schleifer et al., 1985). However, many of the recently delineated taxa were previously unknown, e.g. Alloiococcus (Aguirre \& Collins, 1992b), Dolosigranulum (Aguirre et al., 1993), Facklamia (Collins et al., 1997), Globicatella (Collins et al., 1992), Ignavigranum (Collins et al., 1999) and Helcococcus (Collins et al., 1993a), and

The GenBank accession number for the 16S rRNA gene sequence of Eremococcus coleocola strain CCUG $38207^{\top}$ is $Y 17780$. their recognition has been largely facilitated by the availability of much-improved taxonomic frameworks, which in turn have stemmed from the use of phenotypic and molecular genetic methodologies in concert. Despite this rapid expansion in the number of described taxa, there is a growing awareness that many other genera and species of Gram-positive, catalasenegative cocci remain to be discovered, particularly from human and animal sources. In this study we describe the characteristics of an unknown $\alpha$-haemolytic coccus isolated from the reproductive tract of two horses. On the basis of the results of a polyphasic taxonomic study, we describe yet another new taxon, Eremococcus coleocola gen. nov., sp. nov., within the Gram-positive, catalase-negative cocci.

Strain M1832/95/2 ${ }^{\mathrm{T}}$ was isolated in mixed culture with a Corynebacterium species from a thoroughbred cross horse. This was a follow-up sample for a profuse vaginal discharge that had failed to resolve following treatment. The initial sample had yielded a pure growth of Gardnerella vaginalis. Strain M923/98/1 was isolated from a clitoral fossa swab of a different but apparently healthy thoroughbred mare, which was submitted as a pre-service check. Strains M $1832 / 95 / 2^{\mathrm{T}}$ and M923/98/1 have been deposited in the Culture 
Collection of the University of Göteborg (CCUG) under accession numbers $38207^{\mathrm{T}}$ and 39488 , respectively. Both strains were cultured on Columbia agar (Difco) supplemented with $5 \%$ horse blood at $37{ }^{\circ} \mathrm{C}$, in air plus $5 \% \mathrm{CO}_{2}$. The strains were characterized biochemically by using the API Rapid ID32S and API ZYM systems according to the manufacturer's instructions (API bioMérieux). PAGE analysis of whole-cell proteins was performed as described by Pot et al. (1994). For densitometric analysis, normalization and interpretation of protein patterns, the GELCOMPAR GCW 3.0 software package (Applied Maths) was used. The cell-wall murein structure of strain CCUG $38207^{\mathrm{T}}$ was determined by the method of Schleifer \& Kandler (1972), except that ascending TLC on cellulose sheets (Merck) was used. The $\mathrm{G}+\mathrm{C}$ content of DNA of strain CCUG $38207^{\mathrm{T}}$ was determined as described by Garvie (1978). The 16S rRNA genes of the isolates were amplified by PCR and directly sequenced by using a Taq Dye-Deoxy Terminator Cycle Sequencing Kit (Applied Biosystems) and an automatic DNA sequencer (model 373A; Applied Biosystems). The closest known relatives of the new isolates were determined by performing database searches. These sequences and those of other known related strains were retrieved from the GenBank or Ribosomal Database Project (RDP) databases and aligned with the newly determined sequences by using the program PILEUP (Devereux et al., 1984). The resulting multiple sequence alignment was corrected manually and a distance matrix was calculated by using the programs PRETTY and DNADIST (using Kimura's two-parameter correction) (Felsenstein, 1989). A phylogenetic tree was constructed according to the neighbour-joining method with the program NEIGHBOR (Felsenstein, 1989). The stability of the groupings was estimated by bootstrap analysis (500 replications) using the programs DNABOOT, DNADIST, NEIGHBOR and CONSENSE (Felsenstein, 1989). Parsimony analysis was also performed on the same dataset (Felsenstein, 1989).

The two isolates were ovoid in shape and formed single cells, pairs or short chains. They stained Gram-positive and were $\alpha$-haemolytic on both sheep- and horseblood agar. The isolates were facultatively anaerobic and catalase- and oxidase-negative. They did not grow on Difco Bacto bile aesculin agar. The strains failed to grow at $10^{\circ} \mathrm{C}$ but produced growth at $42{ }^{\circ} \mathrm{C}$. They produced weak growth in $6.5 \% \mathrm{NaCl}$ but not in $10 \%$ $\mathrm{NaCl}$. Using commercial API systems, both strains failed to produce acid from the following carbohydrates tested: D-arabitol, L-arabinose, cyclodextrin, glycogen, lactose, mannitol, melibiose, melezitose, methyl $\beta$-D-glucopyranoside, pullulan, raffinose, ribose, sucrose, sorbitol, tagatose, trehalose and D-xylose. Weak acid production was, however, observed from $\mathrm{N}$-acetylglucosamine. Activities of arginine dihydrolase, pyroglutamic acid arylamidase, esterase $\mathrm{C}-4$ (weak reaction) and ester lipase C-8 (weak reaction) were detected in both strains. Neither of the strains displayed activity for alanine-phenylalanine-proline

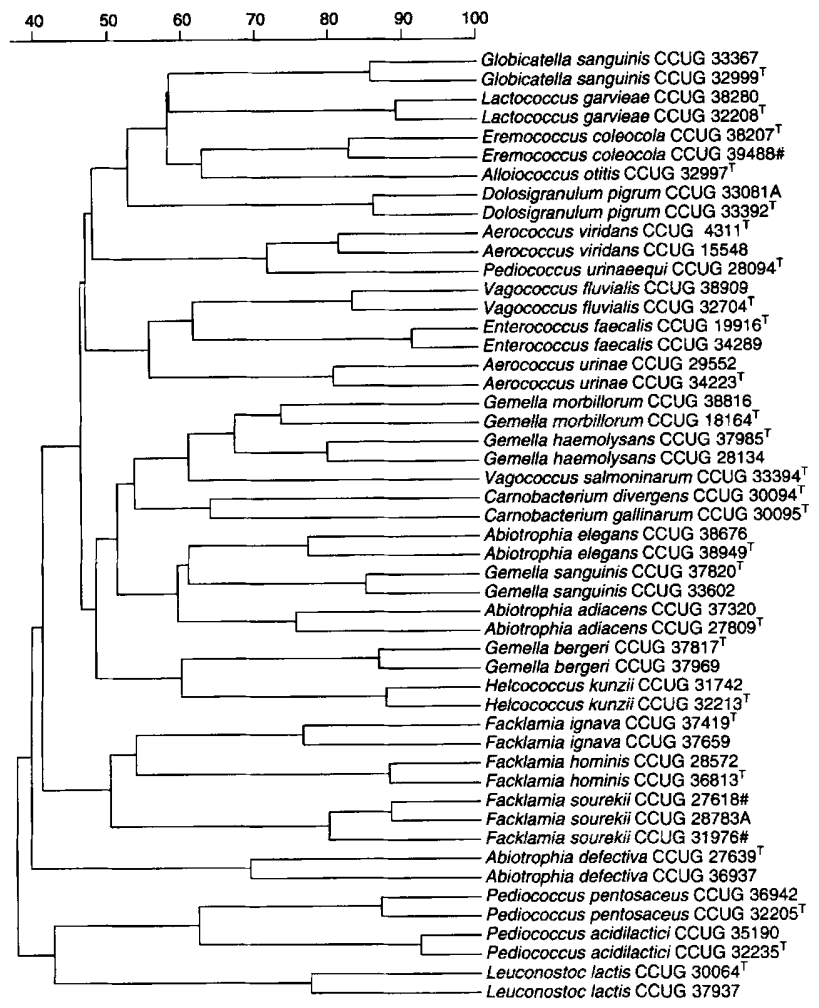

Fig. 1. Similarity dendrogram based on whole-cell protein patterns of Eremococcus coleocola sp. nov. and related species. Levels of correlation are expressed as percentages of similarity for convenience.

arylamidase, leucine arylamidase, valine arylamidase, acid phosphatase, alkaline phosphatase, $\alpha$-fucosidase, $\alpha$-galactosidase, $\beta$-galactosidase, $\beta$-galacturonidase, $\beta$ glucosidase, $\beta$-glucuronidase, glycine-tryptophan arylamidase, $\alpha$-mannosidase, $\beta$-mannosidase, lipase $\mathrm{C} 14$, chymotrypsin, trypsin or pyrazinamidase. Urease activity was variable. Both strains hydrolysed hippurate but did not hydrolyse aesculin, gelatin or starch. PAGE analysis of whole-cell proteins confirmed the close phenotypic resemblance between the two horse isolates. The two strains formed a tight cluster that was quite separate from all other Gram-positive, catalasenegative reference organisms examined (Fig. 1). An examination of the cell wall of strain CCUG $38207^{\mathrm{T}}$ revealed that the unknown coccus possessed a directly cross-linked murein based on L-lysine [type $\mathrm{Al} \alpha$, according to the nomenclature of Schleifer \& Kandler (1972)]. This murein structure is found in a number of Gram-positive, catalase-negative coccus-shaped organisms, such as aerococci (Aguirre \& Collins, 1992a), Alloiococcus otitis (Aguirre \& Collins, 1992b), Globicatella sanguinis (Collins et al., 1992) and Abiotrophia defectiva (Collins et al., 1997), but serves to distinguish the unknown coccus from Dolosigranulum pigrum (Aguirre et al., 1993), Facklamia hominis (Collins et al., 1997) and Facklamia ignava (Collins et al., 1998), which possess an L-lys-D-asp (type A4 4 ) cell wall. To investigate the genealogical affinity between the two 


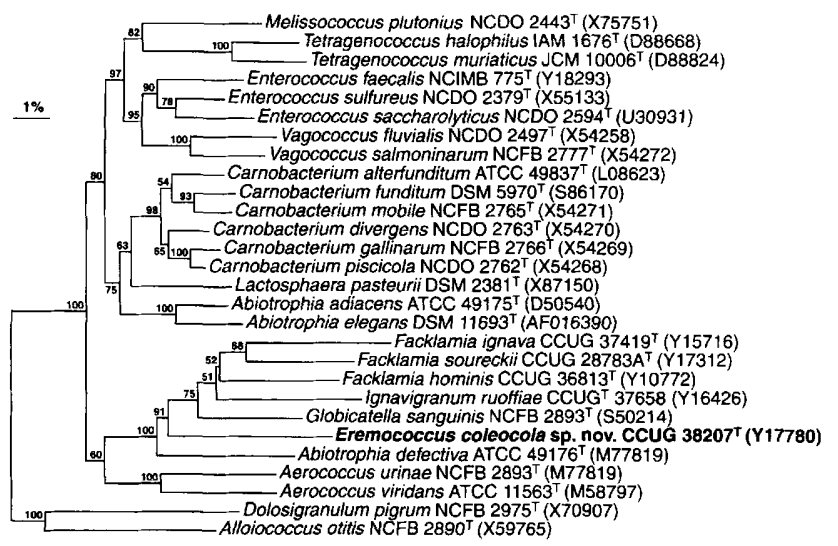

Fig. 2. Unrooted tree showing the phylogenetic relationships of $E$. coleocola and some Gram-positive bacteria. The tree, constructed using the neighbour-joining method, was based on a comparison of approximately 1320 nucleotides. Bootstrap values, expressed as a percentage of 500 replications, are given at branching points. Bar, $1 \%$ sequence divergence.

isolates and their relationship with other Grampositive, catalase-negative taxa, comparative $16 \mathrm{~S}$ rRNA gene sequence analyses were performed. The almost complete gene sequences ( $>1400$ nucleotides) of the two horse strains were determined and pairwise analysis revealed $99.8 \% 16 \mathrm{~S}$ rRNA identity. This close genealogical affinity between the isolates was consistent with the results of whole-cell protein PAGE analysis and their close biochemical resemblance. Sequence searches of GenBank and RDP databases revealed that the unknown isolates were phylogenetically most closely associated with the lactic-acid group of bacteria, particularly Abiotrophia defectiva, Globicatella sanguinis and Facklamia species. A tree constructed by the neighbour-joining method depicting the phylogenetic affinity of the unknown coccus as exemplified by strain CCUG $38207^{\mathrm{T}}$ is shown in Fig. 2 . The coccus formed a distinct line branching between Abiotrophia defectiva and Globicatella sanguinis. The results of the neighbour-joining analysis were confirmed by parsimony analysis.

It is evident from the findings of this investigation that the two strains isolated from mares represent a hitherto unknown bacterium within the Gram-positive, catalase-negative cocci. Phylogenetically, the organism represents a new line within a cluster of organisms that includes Abiotrophia defectiva, Globicatella, Ignavigranum and Facklamia. The coccus from horses exhibits approx. 8-9\% 16S rRNA sequence divergence from the aforementioned taxa, which, together with tree-branching considerations, indicates that the unknown bacterium represents a new taxon at the level of genus. Although the new bacterium shows an apparently closer phylogenetic affinity to Globicatella sanguinis than to other organisms, it can readily be distinguished from the latter by its inability to ferment a broad range of carbohydrates. By contrast, Globicatella sanguinis is highly saccharolytic (Collins et al.,
1992). In terms of its limited ability to ferment carbohydrates, the unknown coccus more closely resembles Ignavigranum ruoffiae, Facklamia hominis and Facklamia ignava (Collins et al., 1997, 1998, 1999). The new coccus, however, differs from Ignavigranum ruoffiae in hydrolysing hippurate and being leucine arylamidase-negative. The horse bacterium can be distinguished from Facklamia hominis by its failure to produce alanine-phenylalanine-proline arylamidase, $\alpha$-galactosidase, $\beta$-galactosidase and leucine arylamidase. Similarly, it differs from Facklamia ignava in being arginine dihydrolase-positive and alanine-phenylalanine-proline arylamidase-negative. Additionally, the unknown coccus contains a directly cross-linked murein based on L-lysine (type A $1 \alpha$ ), in contrast to the A $4 \alpha$ L-lys-D-asp wall type found in Facklamia hominis and Facklamia ignava. On the basis of both phenotypic and phylogenetic findings, we therefore consider that the unknown coccus from horses merits classification within a new genus, and the name Eremococcus coleocola gen. nov., sp. nov. is proposed. Tests that serve to distinguish Eremococcus coleocola from related Gram-positive, catalase-negative cocci are given in Table 1 .

\section{Description of Eremococcus gen. nov.}

Eremococcus (E.re.mo.coc'cus. Gr. adj. eremos lonely; Gr. n. coccus a grain, berry; M.L. n. Eremococcus, a lonely or isolated coccus, referring to its distinct phylogenetic position).

Eremococcus cells are Gram-positive cocci, some of which may be elongated, that occur singly, in pairs or in short chains. $\alpha$-Haemolytic on sheep- and horseblood agar. Facultatively anaerobic and catalasenegative. Does not grow at $10^{\circ} \mathrm{C}$ or in $10 \% \mathrm{NaCl}$. Acid but no gas is produced from glucose. Acid is not produced from most other sugars. Arginine dihydrolase and pyroglutamic acid arylamidase are produced. Leucine arylamidase and alkaline phosphatase are not produced. Hippurate is hydrolysed. Voges-Proskauer negative. The $\mathrm{G}+\mathrm{C}$ content of DNA of the type strain of the type species is $40 \mathrm{~mol} \%$. The cell wall murein type is L-lysine-direct $(\mathrm{A} 1 \alpha)$. The type species of the genus is Eremococcus coleocola.

\section{Description of Eremococcus coleocola sp. nov.}

Eremococcus coleocola (co'le.o.co.la. Gr. n. colea vagina; L. masc. suffix -cola inhabitant; M.L. coleocola inhabitant of the vagina, referring to the isolation of the type strain).

Cells consist of Gram-positive cocci, some of which may be elongated, occurring singly, in pairs or in short chains. Colonies are pin-point, shiny, entire, circular, convex and non-corroding on blood agar after $24 \mathrm{~h} . \alpha$ Haemolytic on horse- and sheep-blood agar. Facultatively anaerobic and catalase-negative. Grows at $42{ }^{\circ} \mathrm{C}$ but not at $10{ }^{\circ} \mathrm{C}$. Grows weakly in $6.5 \% \mathrm{NaCl}$ but not in $10 \% \mathrm{NaCl}$. Does not grow on Difco Bacto 
Table 1. Characteristics that differentiate Eremococcus coleocola gen. nov., sp. nov. from its nearest phylogenetic relatives

Biochemical tests were carried out using API Rapid ID32S and ZYM systems. v, Variable; ND, not determined.

\begin{tabular}{|c|c|c|c|c|c|c|}
\hline Characteristic & A. defectiva & I. ruoffiae & F. hominis & F. ignava & G. sanguinis & E. coleocola \\
\hline \multicolumn{7}{|l|}{ Production of acid from: } \\
\hline Glycogen & + & - & - & - & + & - \\
\hline Lactose & $\mathrm{v}$ & - & - & - & $\mathrm{v}$ & - \\
\hline Mannitol & - & $\mathrm{v}$ & - & - & + & - \\
\hline Melibiose & - & - & - & - & + & - \\
\hline Methyl $\beta$-D-glucopyranoside & - & - & - & - & $\mathrm{v}$ & - \\
\hline Pullulan & + & - & - & - & $\mathrm{v}$ & - \\
\hline Raffinose & $\mathrm{v}$ & - & - & - & + & - \\
\hline Ribose & - & - & - & - & + & - \\
\hline Sorbitol & - & - & - & - & $\mathrm{v}$ & - \\
\hline Sucrose & + & $\mathrm{v}$ & - & - & + & - \\
\hline Trehalose & + & - & - & - & + & - \\
\hline Hydrolysis of hippurate & - & - & + & + & + & + \\
\hline \multicolumn{7}{|l|}{ Production of: } \\
\hline $\begin{array}{l}\text { Alanine-phenylalanine-proline } \\
\text { arylamidase }\end{array}$ & $\mathrm{v}$ & - & + & + & + & - \\
\hline Arginine dihydrolase & - & + & + & - & - & + \\
\hline$\alpha$-Galactosidase & + & - & + & - & + & - \\
\hline$\beta$-Galactosidase & + & - & + & - & + & - \\
\hline Urease & - & + & $\mathrm{v}$ & - & - & $\mathrm{v}$ \\
\hline Leucine arylamidase & + & + & + & - & ND & - \\
\hline Murein type & $\mathrm{A} 1 \alpha$ & $\mathrm{A} 1 \alpha$ & $\mathrm{A} 4 \alpha$ & $\mathrm{A} 4 \alpha$ & $\mathrm{A} 1 \alpha$ & $\mathrm{A} 1 \alpha$ \\
\hline
\end{tabular}

aesculin agar. Acid is produced from glucose. Acid is not produced from L-arabinose, D-arabitol, cyclodextrin, glycogen, lactose, mannitol, maltose, methyl $\beta$-D-glucopyranoside, melibiose, melezitose, pullulan, D-raffinose, D-ribose, sorbitol, sucrose, tagatose, trehalose or D-xylose. Weak acid production from $N$ acetylglucosamine. Arginine dihydrolase, pyroglutamic acid arylamidase, esterase C-4 (weak reaction) and ester lipase C-8 (weak reaction) activities are detected. Urease activity is variable. Alanine-phenylalanine-proline arylamidase, leucine arylamidase, valine arylamidase, acid phosphatase, alkaline phosphatase, $\alpha$-fucosidase, $\alpha$-galactosidase, $\beta$-galactosidase, $\beta$ galacturonidase, $\beta$-glucosidase, $\beta$-glucuronidase, glycine-tryptophan arylamidase, $\alpha$-mannosidase, $\beta$-mannosidase, lipase $\mathrm{C} 14$, chymotrypsin, trypsin and pyrazinamidase activities are not detected. Hippurate is hydrolysed. Aesculin, gelatin and starch are not hydrolysed. Voges-Proskauer negative. Nitrate is not reduced. The $\mathrm{G}+\mathrm{C}$ content of DNA of the type strain is $40 \mathrm{~mol} \%$. The cell wall murein type is L-lysine-direct $(\mathrm{A} 1 \alpha)$. Isolated from horse vaginal and clitoral fossa swabs. The type strain of Eremococcus coleocola is CCUG $38207^{\mathrm{T}}$.

\section{Acknowledgements}

We are grateful to Professor Hans Trüper for coining the genus name. We also thank staff at SAC Veterinary Science
Division at Aberdeen and Inverness for their scientific assistance. SAC Veterinary Science Division receives financial support form the Scottish Office Environment and Fisheries Department.

\section{References}

Aguirre, M. \& Collins, M. D. (1992a). Phylogenetic analysis of some Aerococcus-like organisms from urinary tract infections: description of Aerococcus urinae sp. nov. J Gen Microbiol 138, 401-405.

Aguirre, M. \& Collins, M. D. (1992b). Phylogenetic analysis of Alloiococcus otitis gen. nov., sp. nov., an organism from human middle ear fluid. Int J Syst Bacteriol 42, 79-83.

Aguirre, M., Morrison, D., Cookson, B. D., Gay, F. W. \& Collins, M. D. (1993). Phenotypic and phylogenetic characterization of some Gemella-like organisms from human infections: description of Dolosigranulum pigrum gen. nov., sp. nov. $J$ Appl Bacteriol 75, 608-612.

Collins, M. D., Williams, A.M. \& Wallbanks, S. (1990). The phylogeny of Aerococcus and Pediococcus as determined by $16 \mathrm{~S}$ rRNA sequence analysis: description of Tetragenococcus gen. nov. FEMS Microbiol Lett 58, 255-262.

Collins, M. D., Aguirre, M., Facklam, R. R., Shallcross, J. \& Williams, A. M. (1992). Globicatella sanguis gen. nov., sp. nov., a new gram-positive catalase-negative bacterium from human sources. J Appl Bacteriol 73, 433-437.

Collins, M. D., Facklam, R. R., Rodrigues, U. M. \& Ruoff, K. L. (1993a). Phylogenetic analysis of some Aerococcus-like organ- 
isms from clinical sources: description of Helcococcus kunzii gen. nov., sp. nov. Int J Syst Bacteriol 43, 425-429.

Collins, M. D., Samelis, J., Metaxopoulos, J. \& Wallbanks, S. (1993b). Taxonomic studies on some Leuconostoc-like organisms from fermented sausages: description of a new genus Weissella for the Leuconostoc paramesenteroides group of species. J Appl Bacteriol 75, 595-603.

Collins, M. D., Falsen, E., Lemozy, J., Åkervall, E., Sjödén, B. \& Lawson, P. A. (1997). Phenotypic and phylogenetic characterization of some Globicatella-like organisms from human sources: description of Facklamia hominis gen. nov., sp. nov. Int J Syst Bacteriol 47, 880-882.

Collins, M. D., Lawson, P. A., Monasterio, R., Falsen, E., Sjödén, B. \& Facklam, R. R. (1998). Facklamia ignava sp. nov., isolated from human clinical specimens. J Clin Microbiol 36, 2146-2148.

Collins, M. D., Lawson, P. A., Monasterio, R., Falsen, E., Sjödén, B. \& Facklam, R. R. (1999). Ignavigranum ruoffiae sp. nov., isolated from human clinical specimens. Int J Syst Bacteriol 49, 97-101.

Devereux, J., Haeberli, P. \& Smithies, O. (1984). A comprehensive set of sequence analysis programs for the VAX. Nucleic Acids Res 12, 387-395.

Dicks, L. M. T., Dellaglio, F. \& Collins, M. D. (1995). Proposal to reclassify Leuconostoc oenos as Oenococcus oeni [corrig.] gen. nov., comb. nov. Int J Syst Bacteriol 45, 395-397.
Felsenstein, J. (1989). PHYLIP - Phylogeny inference package (version 3.2). Cladistics 5, 164-166.

Garvie, E. I. (1978). Streptococcus raffinolactis Orla-Jensen and Hansen, a group $\mathrm{N}$ streptococcus found in raw milk. Int $J$ Syst Bacteriol 28, 190-193.

Pot, B., Vandamme, P. \& Kersters, K. (1994). Analysis of electrophoretic whole-organism protein fingerprints. In Modern Microbial Methods (Chemical Methods in Prokaryotic Systematics Series), pp. 493-521. Edited by M. Goodfellow \& A. G. O'Donnell. Chichester: Wiley.

Schleifer, K. H. \& Kandler, O. (1972). Peptidoglycan types of bacterial cells walls and their taxonomic implications. Bacteriol $\operatorname{Rev}$ 36, 407-477.

Schleifer, K. H. \& Kilpper-Bälz, R. (1984). Transfer of Streptococcus faecalis and Streptococcus faecium to the genus Enterococcus nom. rev. as Enterococcus faecalis comb. nov. and Enterococcus faecium comb. nov. Int J Syst Bacteriol 34, 31-34.

Schleifer, K. H., Kraus, J., Dvorak, C., Kilpper-Bälz, R., Collins, M. D. \& Fischer, W. (1985). Transfer of Streptococcus lactis and related streptococci to the genus Lactococcus gen. nov. Syst Appl Microbiol 6, 183-195.

Sneath, P. H. A., Mair, N. S., Sharpe, M. E. \& Holt, J. G. (editors) (1986). Bergey's Manual of Systematic Bacteriology, vol. 2. Baltimore: Williams \& Wilkins. 